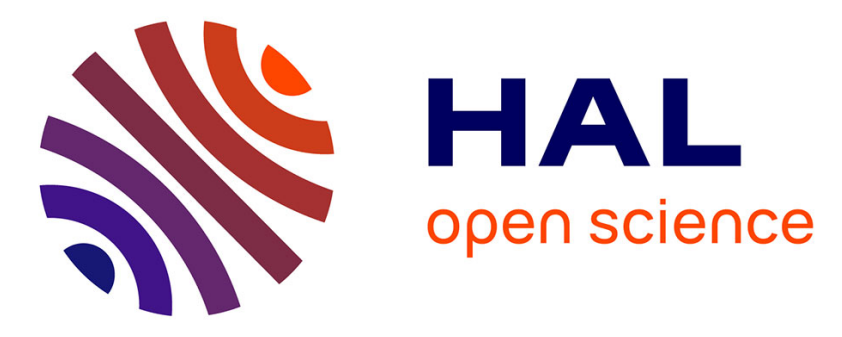

\title{
Polymer micelles decorated by gadolinium complexes as MRI blood contrast agents: design, synthesis and properties
}

\author{
M. Grogna, R. Cloots, A. Luxen, Christine Jérôme, Catherine \\ Passirani-Malleret, Nolwenn Lautram, J.-F. Desreux, Christophe Detrembleur
}

\section{- To cite this version:}

M. Grogna, R. Cloots, A. Luxen, Christine Jérôme, Catherine Passirani-Malleret, et al.. Polymer micelles decorated by gadolinium complexes as MRI blood contrast agents: design, synthesis and properties. Polymer Chemistry, 2010, 1, pp.1485-90. hal-03171869

\section{HAL Id: hal-03171869 \\ https://univ-angers.hal.science/hal-03171869}

Submitted on 17 Mar 2021

HAL is a multi-disciplinary open access archive for the deposit and dissemination of scientific research documents, whether they are published or not. The documents may come from teaching and research institutions in France or abroad, or from public or private research centers.
L'archive ouverte pluridisciplinaire HAL, est destinée au dépôt et à la diffusion de documents scientifiques de niveau recherche, publiés ou non, émanant des établissements d'enseignement et de recherche français ou étrangers, des laboratoires publics ou privés. 


\title{
Polymer micelles decorated by gadolinium complexes as MRI blood contrast agents: design, synthesis and properties
}

\author{
Mathurin Grogna, ${ }^{a}$ Rudi Cloots, ${ }^{b}$ André Luxen, ${ }^{c}$ Christine Jérôme, ${ }^{a}$ Catherine Passirani, ${ }^{d}$ Nolwenn Lautram, ${ }^{d}$ \\ Jean-F. Desreux ${ }^{e}$ and Christophe Detrembleur $* a$
}

\author{
Received 16th April 2010, Accepted 9th July 2010 \\ DOI: 10.1039/c0py00117a
}

New micellar macrocontrast agents with improved contrast at high frequencies were designed by grafting a gadolinium based contrast agent onto functional stealth micelles formed by poly(ethylene oxide)- $b$-poly( $\varepsilon$-caprolactone) (PEO- $b$-PCL) in water. As evidenced by relaxometry measurements and the hemolytic $\mathrm{CH} 50$ test, the new contrast agents are of interest as MRI blood pool agents.

\section{Introduction}

Nuclear Magnetic Resonance Imaging (MRI) is presently the leading imaging modality in diagnostic medicine. ${ }^{1}$ MRI is noninvasive and allows imaging biological objects (soft tissues for instance) and processes at the molecular level. The image contrast in MRI depends essentially on differences in relaxation times and proton density between different tissues. To reach the full potential of MRI for advanced imaging applications, the inherently low sensitivity of MRI has to be enhanced with contrast agents (CAs) containing paramagnetic metal ions such as $\mathrm{Gd}(\mathrm{III}){ }^{2}$

The contrast agents currently approved for clinical uses are based on low molecular weight Gd(III) chelates, such as Magnevist ${ }^{\circledR}$ and Dotarem ${ }^{\circledR}$ (Scheme 1). However, modern MRI instruments are operating at high magnetic fields ${ }^{3-5}$ (i.e. frequencies) where contrast agents have a low relaxivity (the longitudinal relaxation rates per second and per mmol of metal ion that governs the contrasting efficiency). Consequently, relatively large amounts of these potentially toxic contrast agents are needed per injection and further improvements are required to alleviate this problem. Three main directions can be considered for that purpose: (1) enhancing the relaxivity of $\mathrm{Gd}(\mathrm{III})$ based
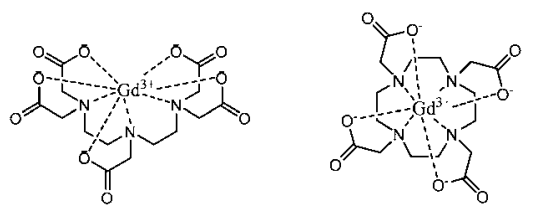

Scheme 1 Clinically used contrast agents for MRI (left: Magnevist ${ }^{\circledR}$ and right: Dotarem $\left.{ }^{\circledR}\right)$.

${ }^{a}$ Center for Education and Research on Macromolecules (CERM) University of Liège, B6 Sart-Tilman, B-4000 Liège, Belgium. E-mail: christophe.detrembleur@ulg.ac.be; Fax: +32 4-3663497; Tel: +32 43663465

${ }^{b}$ Laboratoire de chimie inorganique structurale, University of Liège, B6 Sart Tilman, B-4000 Liège, Belgium

${ }^{c}$ Cyclotron Research Centre, University of Liège, B6 Sart Tilman, B-4000 Liège, Belgium

${ }^{d}$ INSERM, U 646, 10 Rue A Boquel, 49000 Angers, France

${ }^{e}$ Coordination and Radiochemistry, University of Liège, B6 Sart Tilman, B4000 Liège, Belgium complexes, (2) improving the circulation lifetime in the case of blood pool agents, and (3) targeting them to the desired tissue. Firstly, the relaxivity of $\mathrm{Gd}(\mathrm{III})$ based complexes can be much improved by reducing their tumbling rate in solution. Slowing down rotational motions was successfully achieved by immobilizing gadolinium complexes onto macromolecules of different sizes and shapes (proteins, ${ }^{6-10}$ polylysine, ${ }^{11}$ dendrimers, ${ }^{12-14}$ polysaccharides (i.e. dextran ${ }^{15,16}$ ) and micelles (or liposomes) ${ }^{4,17-21}$ ). Although those strategies have allowed to push rotational correlation times to their theoretical maximum, they are all too often compromised either by nonoptimal water residency times, poor solubility in water, reduced target affinity and selectivity, or lack of realistic usefulness in the actual application. The pharmacokinetic behavior of these agents is also a concern and has to be determined case-by-case. ${ }^{21}$ Secondly, the decoration of high molecular weight metal complexes by stealth molecules (such as polyethylene oxide, PEO) is a way to increase their blood residence time that allows ill tissues to be reached. ${ }^{22}$ Finally, the efficacy of the contrast agents can be improved by functionalizing them with targeting peptides ${ }^{\mathbf{2 0 , 2 3}}$ and/or by grafting them to macromolecules that passively target tumor tissues through a combination of reduced renal clearance and exploitation of the enhanced permeation and retention (EPR) effect, which prevails for fast-growing tumors. ${ }^{24-26}$

In the following studies, we aim at designing novel gadolinium based blood pool contrast agents ${ }^{3}$ with improved relaxivity at high frequencies resulting from the grafting in mild conditions of the gadolinium complex (S-2-(4-aminobenzyl)-diethylenetriamine

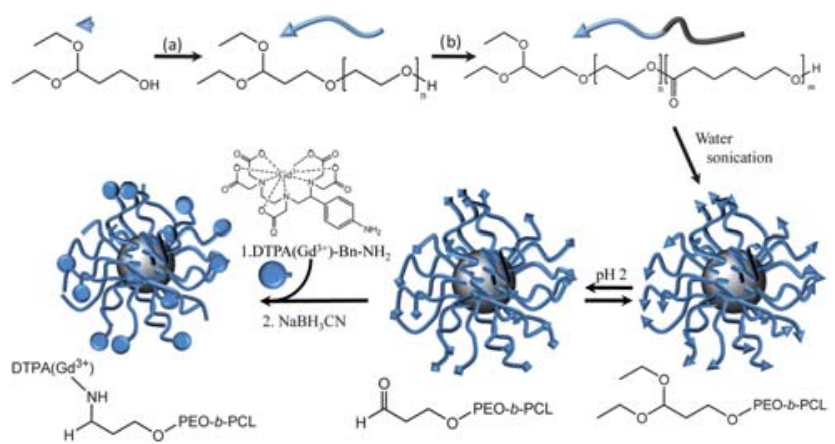

Scheme 2 General procedure for the synthesis of the macromolecular contrast agent [(a) (1) Napht-K, EO (THF, $40{ }^{\circ} \mathrm{C}$ ); and (2) isopropanol; and (b) $\mathrm{Sn}(\mathrm{oct})_{2}, \varepsilon-\mathrm{CL}$ (toluene, $120^{\circ} \mathrm{C}$ )]. 
pentaacetic acid, p-NH$-\mathrm{Bn}-\mathrm{DTPA}\left(\mathrm{Gd}^{3+}\right)$, Scheme 2) at the surface of biocompatible micelles formed by an amphiphilic poly(ethylene oxide)- $b$-poly( $\varepsilon$-caprolactone) block copolymer (PEO- $b$-PCL) in water. The relaxivity should be improved by decreasing the tumbling rate of the gadolinium complex while the PEO chains should ensure the repulsion of opsonins allowing for a prolonged blood circulation. These improvements are intensively searched for decreasing the doses of gadolinium required per injection while maintaining satisfactory image acquisition times.

\section{Experimental section}

\section{General procedures}

Commercial tetrahydrofuran (THF), 3,3-diethoxy-1-propanol, naphthalene, toluene, heptane, isopropanol, tin(II) 2-ethylhexanoate $\left[\mathrm{Sn}(\mathrm{oct})_{2}\right.$, tin octoate, 95\%], 6-aminofluorescein and caprolactone ( $\varepsilon-\mathrm{CL}$ ) were purchased from Sigma-Aldrich. $S$-2(4-Aminobenzyl)-diethylenetriamine pentaacetic acid ( $\mathrm{p}-\mathrm{NH}_{2}-$ Bn-DTPA) was purchased from Macrocyclics. Ethylene oxide (EO, 99.9\%) was purchased from Chemogas and was used as received. $\varepsilon$-Caprolactone ( $\varepsilon$-CL) was dried over calcium hydride at room temperature for $48 \mathrm{~h}$ and distilled under reduced pressure just before use. THF and toluene were dried with a sodium/benzophenone system and distilled just before use.

\section{Synthesis}

Synthesis of $\boldsymbol{\alpha}$-acetal-PEO-OH. $\alpha-\mathrm{PEO}_{(4000)}-\mathrm{OH}$ was synthesized by ring-opening polymerization of EO as follows. Naphthalene (1.21 g, $9.45 \mathrm{mmol}$ ) was dissolved in $250 \mathrm{ml}$ of dried THF in a glass reactor, followed by the addition of $0.3 \mathrm{~g}$ of potassium $(7.88 \mathrm{mmol})$. The mixture was stirred at room temperature during 3 hours and the color turned to dark-green corresponding to the formation of the naphthalene/K complex. This mixture was added to a solution of $0.99 \mathrm{ml}(6.3 \mathrm{mmol})$ of 3,3-diethoxy-1propanol dissolved in $200 \mathrm{ml}$ of dried THF. After $10 \mathrm{~min}$ of stirring, the solution was transferred to a 11 stainless steel reactor and $25 \mathrm{~g}(0.57 \mathrm{~mol})$ of EO were added to the solution. The polymerization of EO proceeded for $4 \mathrm{~h}$ at $50{ }^{\circ} \mathrm{C}$. An excess of isopropanol $(10 \mathrm{ml})$ was then added to stop the reaction and the polymer was quantitatively recovered by precipitation into a large volume of heptane and was dried under vacuum. Polymer was analyzed by ${ }^{1} \mathrm{H}$ NMR and size exclusion chromatography.

${ }^{1} \mathrm{H}$ NMR $\left(\mathrm{CDCl}_{3}, \mathrm{TMS}, 250 \mathrm{MHz}\right): \delta=1.19 \mathrm{ppm}(\mathrm{t}, 6 \mathrm{H}$, $\left.\mathrm{CH}_{3}-\mathrm{CH}_{2}-\right), \delta=1.88 \mathrm{ppm}\left(\mathrm{q}, 2 \mathrm{H},-\mathrm{CH}-\mathrm{CH}_{2}-\mathrm{CH}_{2}-\right), \delta=$ $3.65 \mathrm{ppm}\left(\mathrm{m}, 364 \mathrm{H},-\mathrm{CH}_{2}-\mathrm{CH}_{2}-\mathrm{O}-\right)$, $\delta=4.63 \mathrm{ppm}(\mathrm{t}, 1 \mathrm{H},-\mathrm{O}-$ $\left.\mathrm{C} H-\mathrm{CH}_{2}-\right) \cdot M_{\mathrm{n}, \mathrm{NMR}}=4000 \mathrm{~g} \mathrm{~mol}^{-1}, \mathrm{DP}_{\mathrm{n}, \mathrm{NMR}}=91, M_{\mathrm{n}, \mathrm{SEC}}=$ $3900 \mathrm{~g} \mathrm{~mol}^{-1}, M_{\mathrm{w}} / M_{\mathrm{n}}=1.11$.

$\alpha$-Acetal-PEO $1600-\mathrm{OH}$ and $\alpha$-acetal- $\mathrm{PEO}_{2500}-\mathrm{OH}$ were synthesized using the same experimental procedure, except that the monomer to initiator ratio was adapted accordingly.

Synthesis of $\alpha$-acetal-PEO- $b$-PCL. $\alpha$-Acetal-PEO- $b$-PCL was synthesized by ring-opening polymerization of $\varepsilon$-CL according to the following general procedure described elsewhere. ${ }^{27,28} 1 \mathrm{~g}$ of $\alpha$-acetal- $\mathrm{PEO}_{4000}-\mathrm{OH}\left(2.5 \times 10^{-4} \mathrm{~mol}\right)$ was dried under reduced pressure at $100{ }^{\circ} \mathrm{C}$ for $10 \mathrm{~h}$ in a glass reactor and then dissolved in $10 \mathrm{ml}$ of dried toluene. $\varepsilon-\mathrm{CL}(0.65 \mathrm{ml}, 0.65 \mathrm{~mol})$ and $\mathrm{Sn}(\mathrm{Oct})_{2}$ $\left(0.83 \mathrm{ml}\right.$ of a $0.06 \mathrm{M}$ solution (in toluene), $5 \times 10^{-6} \mathrm{~mol}$ $(0.02$ equiv./OH $))^{29}$ were added to the acetal-PEO-OH solution. The polymerization of $\varepsilon$-CL proceeded for $5 \mathrm{~h}$ at $120{ }^{\circ} \mathrm{C}$. The copolymer was quantitatively recovered by precipitation into a large volume of heptane and dried over vacuum. The copolymer was analyzed by ${ }^{1} \mathrm{H}$ NMR spectroscopy and SEC.

${ }^{1} \mathrm{H}$ NMR $\left(\mathrm{CDCl}_{3}\right.$, TMS, $\left.250 \mathrm{MHz}\right): \delta=1.19\left(\mathrm{t}, 6 \mathrm{H}, \mathrm{CH}_{3}-\right.$ $\left.\mathrm{CH}_{2}-\right), \delta=1.37\left(\mathrm{~m}, 46 \mathrm{H},-\mathrm{CH}_{2}-\mathrm{CH}_{2}-\mathrm{CH}_{2}-\mathrm{CH}_{2}-\mathrm{CH}_{2}-\mathrm{O}-\right), \delta=$ $1.64\left(\mathrm{~m}, 92 \mathrm{H},-\mathrm{CH}_{2}-\mathrm{CH}_{2}-\mathrm{CH}_{2}-\mathrm{CH}_{2}-\mathrm{CH}_{2}-\mathrm{O}-\right), \delta=2.30(\mathrm{t}$, $\left.46 \mathrm{H},-\mathrm{CH}_{2}-\mathrm{CH}_{2}-\mathrm{CH}_{2}-\mathrm{CH}_{2}-\mathrm{CH}_{2}-\mathrm{O}-\right), \delta=3.65(\mathrm{~m}, 364 \mathrm{H}$, $\left.-\mathrm{CH}_{2}-\mathrm{CH}_{2}-\mathrm{O}-\right), \delta=4.05\left(\mathrm{t}, 46 \mathrm{H},-\mathrm{CH}_{2}-\mathrm{CH}_{2}-\mathrm{CH}_{2}-\mathrm{CH}_{2}-\mathrm{CH}_{2}-\right.$ $\mathrm{O}-), \delta=4.63\left(\mathrm{t}, 1 \mathrm{H},-\mathrm{O}-\mathrm{CH}-\mathrm{CH}_{2}-\right) . M_{\mathrm{n}, \mathrm{NMR}}=6600 \mathrm{~g} \mathrm{~mol}^{-1}$, $\mathrm{DP}_{\mathrm{n}, \mathrm{NMR}}=114, M_{\mathrm{n}, \mathrm{SEC}}=6100 \mathrm{~g} \mathrm{~mol}^{-1}, M_{\mathrm{w}} / M_{\mathrm{n}}=1.16$.

Micelle formation. $150 \mathrm{mg}$ of copolymer were dissolved in $3 \mathrm{ml}$ of THF. After complete dissolution, the solution was added dropwise under vigorous sonication in $50 \mathrm{ml}$ of water. The solution was stirred overnight at room temperature to remove THF.

Conversion of acetal into aldehyde end groups. The conversion of the acetal end group into an aldehyde function was conducted after the micelle formation previously described. The $\mathrm{pH}$ of the micellar copolymer solution was decreased to 2 by the addition of $\mathrm{HCl} 0.1 \mathrm{M}$ during $2 \mathrm{~h}$. The $\mathrm{pH}$ was then increased to 7 by the slow addition of a $\mathrm{NaOH} 0.1 \mathrm{M}$ solution. Finally, the solution was dialyzed for $48 \mathrm{~h}$ against distilled water (Spectra/Por dialysis membrane, molecular weight cut-off, 6000/8000). The dialysate was exchanged four times. Finally, the solution was lyophilized and analyzed by ${ }^{1} \mathrm{H}$ NMR to quantify the aldehyde conversion.

${ }^{1} \mathrm{H}$ NMR $\left(\mathrm{CDCl}_{3}, \mathrm{TMS}, 250 \mathrm{MHz}\right): \delta=1.37(\mathrm{~m}, 46 \mathrm{H}), \delta=$ $1.64(\mathrm{~m}, 92 \mathrm{H}), \delta=2.30(\mathrm{t}, 46 \mathrm{H}), \delta=3.65(\mathrm{~m}, 364 \mathrm{H}), \delta=4.05(\mathrm{t}$, $46 \mathrm{H}), \delta=9.35(\mathrm{~s}, 0.6 \mathrm{H}) \cdot M_{\mathrm{n}, \mathrm{NMR}}=6600 \mathrm{~g} \mathrm{~mol}^{-1}, \mathrm{DP}_{\mathrm{n}, \mathrm{NMR}}=$ $114, M_{\mathrm{n}, \mathrm{SEC}}=6100 \mathrm{~g} \mathrm{~mol}^{-1}, M_{\mathrm{w}} / M_{\mathrm{n}}=1.16$.

Preparation of the $\mathbf{G d}^{3+}$ complex with $\mathrm{NH}_{2}$-Bn-DTPA. Ligand [S-2-(4-aminobenzyl)-diethylenetriamine pentaacetic acid] ( $\mathrm{NH}_{2}$-Bn-DTPA) (644 mg, $1 \mathrm{mmol}$ ) was dissolved in $5 \mathrm{ml}$ water. $\mathrm{GdCl}_{3} \cdot 6 \mathrm{H}_{2} \mathrm{O}(409 \mathrm{mg}, 1.1 \mathrm{mmol})$ was added to this solution and the $\mathrm{pH}$ was increased to 6 by the addition of a $\mathrm{KOH}(1 \mathrm{M})$ solution. The solution was heated at $40{ }^{\circ} \mathrm{C}$ overnight. Finally, the uncomplexed $\mathrm{Gd}^{3+}$ ions were removed by eluting the solution through a Chelex 100 (Bio-Rad Laboratories, sodium form) resin. The resulting solution was brought to dryness under reduced pressure and the $\mathrm{NH}_{2}-\mathrm{Bn}-\mathrm{DTPA}\left(\mathrm{Gd}^{3+}\right)$ complex was recovered as a pale yellow solid in almost quantitative yield $(>95 \%) \cdot \mathrm{MS}\left(\mathrm{ESI}^{-}\right): \mathrm{m} / z: 637[\mathrm{M}-\mathrm{H}]^{-}$.

Synthesis of macrocontrast agent (DTPA $\left(\mathrm{Gd}^{3+}\right)-\mathrm{PEO}-b$-PCL): conjugation of $\mathrm{NH}_{2}-\mathrm{Bn}-\mathrm{DTPA}\left(\mathrm{Gd}^{3+}\right)$ to aldehyde-PEO-b-PCL. $\mathrm{NH}_{2}$-Bn-DTPA $\left(\mathrm{Gd}^{3+}\right)$ was grafted to $\alpha$-aldehyde-PEO $\mathrm{P}_{4000}-b$ $\mathrm{PCL}_{2600}$ by reductive amination according to the following optimized conditions. $100 \mathrm{mg}$ of $\alpha$-aldehyde-PEO $\mathrm{P}_{4000}-b$-PCL 2600 ( $15 \mu \mathrm{mol}$ of aldehyde group) were placed in $2 \mathrm{ml}$ THF and added drop by drop to $40 \mathrm{ml}$ of sodium carbonate/sodium hydrogen carbonate buffer solution $\left(0.1 \mathrm{~mol} \mathrm{l}^{-1}, \mathrm{pH}=7\right) .9 .65 \mathrm{mg}$ of $\mathrm{NH}_{2^{-}}$ $\mathrm{Bn}-\mathrm{DTPA}\left(\mathrm{Gd}^{3+}\right)(15 \mu \mathrm{mol})$ were added to this solution. The solution was stirred for $1 \mathrm{~h}$. Sodium cyanoborohydride $(0.15 \mathrm{ml}$ of a $1 \mathrm{M}$ solution in THF, $150 \mu \mathrm{mol}$ ) was added and the mixture 
was allowed to stir for $96 \mathrm{~h}$. Unreacted reagents were removed by dialysis (Spectra/Por, molecular weight cut-off 6000/8000) against water for $48 \mathrm{~h}$. Finally, the micelles were lyophilized. The grafting yield $(60 \%)$ was determined by quantifying gadolinium in the final purified product by inductive coupling plasma (ICP) analysis.

\section{Characterizations}

${ }^{1} \mathrm{H}$ NMR spectra of the different polymers were recorded at $298 \mathrm{~K}$ with a Bruker spectrometer $(250 \mathrm{MHz})$ in $\mathrm{CDCl}_{3}((D 1) 2 \mathrm{~s}$, 16 scans, $5 \mathrm{wt} \%$ of polymer). Size exclusion chromatography (SEC) of the polymers was carried out in dimethylformamide containing $25 \mathrm{mM} \mathrm{LiBr}$ (flow rate: $1 \mathrm{ml} \mathrm{min}^{-1}$ ) at $55{ }^{\circ} \mathrm{C}$ with a Waters 600 liquid chromatrograph equipped with a 410 refractive index detector and four Waters Styragel columns [HR 1 (100-5000), HR 3 (500-30 000), HR 4 (5000-500 000), and HR $5(2000-4000000)(7.8 \times 300 \mathrm{~mm})]$. Poly(ethylene glycol) standards were used for calibration. Copolymers were analyzed for their size and charge distribution using a Malvern Zetasizer ${ }^{\circledR}$ Nano Series DTS 1060 (Malvern Instruments S.A., Worcestershire, UK). Copolymers concentrations were adjusted to $1 \mathrm{mg} \mathrm{ml}^{-1}$ in a solution composed of $750 \mu \mathrm{l}$ of deionised water and $250 \mu \mathrm{l}$ of Veronal-buffered saline containing $0.15 \mathrm{mM} \mathrm{Ca}^{2+}$ and $0.5 \mathrm{mM} \mathrm{Mg}^{2+}$ in order to ensure a convenient scattered intensity on the detector.

Field cycling relaxometry. The water proton NMRD profiles were measured at $25^{\circ} \mathrm{C}$ on a Stelar fast field-cycling spectrometer FFC-2000 in water between 0.0002 and $1.88 \mathrm{~T}$ (corresponding to $0.01-80 \mathrm{MHz}$ proton Larmor frequencies). The ${ }^{1} \mathrm{H} T_{1}$ relaxation times were acquired by the standard inversion recovery method with a typical $90^{\circ}$ pulse width of $3.5 \mu \mathrm{s}$, using 16 experiments of 4 scans.

Inductive coupling plasma (ICP). The gadolinium concentration of the macrocontrast agent was determined by inductively coupled plasma mass spectrometry (ICP-MS), carried out on a DRC II spectrometer (Perkin Elmer). Samples were prepared by reaction of $1.5 \mathrm{ml}$ of the macrocontrast agent solution with $2 \mathrm{ml}$ of $\mathrm{HNO}_{3}(65 \%)$ at room temperature for $2 \mathrm{~h}$. The solution was then diluted to $100 \mathrm{ml}$ with bidistilled water prior to ICP-MS analysis.

\section{Complement consumption testing (CH50 test)}

Complement consumption was assessed in normal human serum (NHS) (provided by the Etablissement Français du Sang, CHU, Angers, France) by measuring the residual haemolytic capacity of the complement system after contact with particles. The technique consisted in determining the amount of serum able to lyse $50 \%$ of a fixed number of sensitized sheep erythrocytes with rabbit antisheep erythrocyte antibodies $(\mathrm{CH} 50)$, according to the procedure described elsewhere. ${ }^{30,31}$ Complement activation was expressed as a function of the surface in order to compare particles with different mean diameters. Nanoparticle surface areas were calculated as described elsewhere, ${ }^{32}$ using the equation: $S=n 4 \pi r^{2}$ and $V=n(4 / 3)\left(\pi r^{3}\right)$ leading to $S=3 m / r \rho$ where $S$ is the surface area $\left(\mathrm{cm}^{2}\right)$ and $V$ the volume $\left(\mathrm{cm}^{3}\right)$ of $n$ spherical beads of average radius $r(\mathrm{~cm})$, weight $m(\mu \mathrm{g})$ and volumetric mass $\rho\left(\mu \mathrm{g} \mathrm{cm}^{-3}\right)$.

\section{Results and discussion}

\section{Synthesis of the macrocontrast agent (DTPA $\left(\mathrm{Gd}^{3+}\right)$-PEO- $b$ - PCL)}

The general procedure for the synthesis of the macrocontrast agent consists in first preparing an aldehyde functionalized poly(ethylene oxide)- $b$-poly( $\varepsilon$-caprolactone) (ald-PEO- $b$-PCL) diblock copolymer, followed by imination with $S$-2-(4-aminobenzyl)-diethylenetriamine pentaacetic acid $\left(\mathrm{NH}_{2}-\mathrm{Bn}-\mathrm{DTPA}\left(\mathrm{Gd}^{3+}\right)\right)$ and reduction with sodium cyanoborohydride (Scheme 2).

The procedure described by Scholz et al. ${ }^{28}$ for the synthesis of aldehyde-ended poly(ethylene glycol)- $b$-poly(lactide) block copolymer was adapted for the preparation of the aldehyde functionalized poly(ethylene glycol)- $b$-poly( $\varepsilon$-caprolactone) (Scheme 2).

We first synthesized poly(ethylene oxide) of different molecular weights $\left(M_{\mathrm{n}}=1300-2500-4000 \mathrm{~g} \mathrm{~mol}^{-1}\right)$ bearing an acetal group at the $\alpha$ position ( $\alpha$-acetal-PEO-OH) by ring-opening polymerization of EO using potassium 3,3-diethoxy-1-propanolate as initiator, as reported elsewhere. ${ }^{27} \mathrm{Next}$, the terminal hydroxyl group of $\alpha$-acetal-PEO-OH was used to initiate the ring-opening polymerization of $\varepsilon$-caprolactone with $\mathrm{Sn}(\text { oct })_{2}$ to produce the corresponding block copolymer $\alpha$-acetal-PEO- $b$ PCL. The composition and polydispersity of the prepared copolymers have been determined by ${ }^{1} \mathrm{H}$ NMR and SEC, respectively, and are summarized in Table 1 (columns 2 and 3). After precipitation and drying, the copolymer was dissolved in THF and added dropwise to water under vigorous sonication to form the block copolymer micelles with a hydrophobic PCL core and a hydrophilic PEO corona bearing the acetal groups. Deprotection of the acetal groups into aldehyde was performed by decreasing the $\mathrm{pH}$ of the solution to 2 . Finally, the $\mathrm{pH}$ was increased to 7 and the product was dialyzed against water. Lyophilization led to the corresponding aldehyde functional copolymer ( $\alpha$-aldehyde-PEO ${ }_{4000}-b$ - $\mathrm{PCL}_{2600}$ ). ${ }^{1} \mathrm{H}$ NMR analysis

Table 1 Data of acetal-PEO- $b$-PCL, aldehyde-PEO- $b$-PCL and DTPA $\left(\mathrm{Gd}^{3+}\right)$-PEO- $b$-PCL block copolymers and their micelles

\begin{tabular}{|c|c|c|c|c|c|c|}
\hline \multirow[b]{2}{*}{ Entry } & \multicolumn{2}{|c|}{$\begin{array}{l}\text { NMR and SEC data of } \\
\text { acetal-PEO- } b \text {-PCL (in } \\
\mathrm{CDCL}_{3} \text { and DMF } \\
\text { respectively) }\end{array}$} & \multicolumn{2}{|c|}{$\begin{array}{l}\text { DLS data of } \\
\text { aldehyde-PEO- } b \text { - } \\
\text { PCL micelles in } \\
\text { water }\end{array}$} & \multicolumn{2}{|c|}{$\begin{array}{l}\text { DLS data of } \\
\text { DTPA }\left(\mathrm{Gd}^{3+}\right)- \\
\text { PEO- } b \text {-PCL } \\
\text { micelles in water }\end{array}$} \\
\hline & $\begin{array}{l}M_{\mathrm{n}} / \mathrm{g} \\
\mathrm{mol}^{-1}(\mathrm{DP})^{a}\end{array}$ & $\begin{array}{l}M_{\mathrm{w}} / \\
M_{\mathrm{n}}{ }^{b}\end{array}$ & $\begin{array}{l}\text { Diameter }{ }^{c} / \\
\mathrm{nm}\end{array}$ & $\mathrm{PDI}^{d}$ & $\begin{array}{l}\text { Diameter }{ }^{c} / \\
\mathrm{nm}\end{array}$ & $\mathrm{PDI}^{d}$ \\
\hline 1 & $1300-b-1500(30-13)$ & 1.16 & 15 & 0.24 & 20 & 0.22 \\
\hline & 1300 & 1.19 & 2 & & 30 & 0.18 \\
\hline & 2500 & 1.17 & 12 & & 2 & 0.28 \\
\hline 4 & 2500 & 1.18 & 26 & & 35 & \\
\hline 5 & $2500-b-5000(57-44)$ & 1.15 & 40 & 0.28 & 49 & 0.3 \\
\hline 6 & $4000-b-1600(91-14)$ & 1.16 & 30 & 0.3 & 40 & 0.27 \\
\hline 7 & $4000-b-2600(91-23)$ & 1.18 & 37 & 0.25 & 50 & 0.27 \\
\hline \multicolumn{7}{|c|}{$\begin{array}{l}{ }^{a} \text { Degree of polymerization }[\mathrm{DP}] \text { determined by NMR. }{ }^{b} \text { Molecular } \\
\text { weight distribution determined by size exclusion chromatography. } \\
{ }^{c} \text { Micelles diameter. }{ }^{d} \text { Polydispersity determined by dynamic light } \\
\text { scattering. }\end{array}$} \\
\hline
\end{tabular}




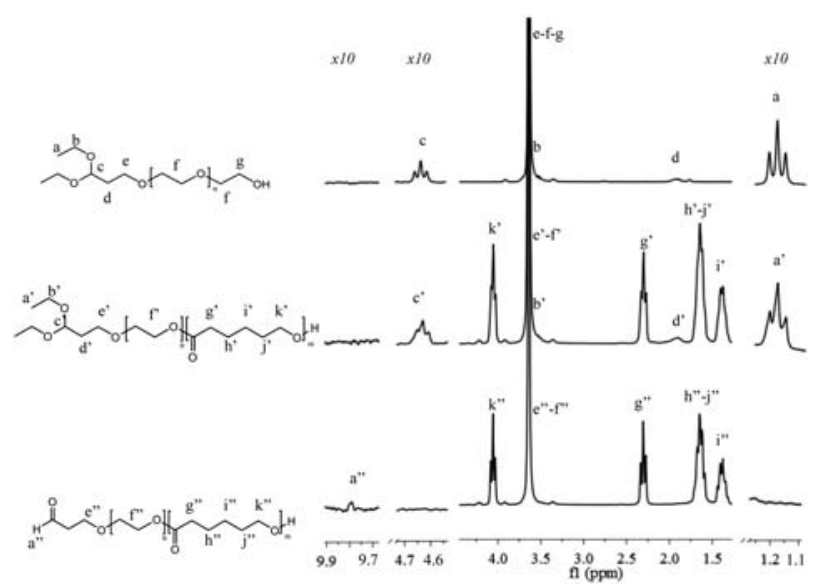

Fig. $1{ }^{1} \mathrm{H}$ NMR spectra of $\alpha$-acetal-PEO ${ }_{4000}-\mathrm{OH}$ (top), $\alpha$-acetal$\mathrm{PEO}_{4000}-b-\mathrm{PCL}_{2600}$ (middle) and $\alpha$-aldehyde- $\mathrm{PEO}_{4000}-b-\mathrm{PCL}_{260}$ (bottom).

(Fig. 1) of the block copolymer before and after deprotection allowed us to demonstrate that the reaction was quantitative thanks to the complete disappearance of the typical peaks of the acetal groups at $1.19 \mathrm{ppm}\left(-\mathrm{O}-\mathrm{CH}-\mathrm{CH}_{2}-\mathrm{CH}_{3}\right)$ and $4.63 \mathrm{ppm}$ $\left(-\mathrm{O}-\mathrm{CH}-\mathrm{CH}_{2}-\mathrm{CH}_{3}\right)$. The appearance of a singlet at $9.35 \mathrm{ppm}$ is characteristic of the aldehyde function that represents however only $60 \%$ of the initial acetal groups. This discrepancy is the result of the aldehyde/hydrate equilibrium that establishes itself easily in water. ${ }^{33}$

Size exclusion chromatography analysis of the block copolymer before (B curve, Fig. 2) and after (C curve, Fig. 2) deprotection clearly shows that no degradation of the PCL block occurred in these mild experimental conditions.

The aldehyde functional PEO- $b$-PCL micelles in water $\left(0.5 \mathrm{mg} \mathrm{ml}^{-1}\right)$ with a hydrophobic PCL core and a hydrophilic PEO corona bearing the aldehyde groups have been characterized by dynamic light scattering measurements (Table 1, columns 4 and 5). Depending on the size and composition of the block

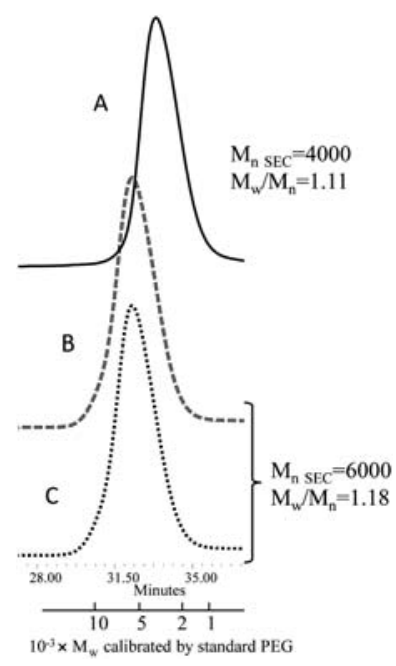

Fig. 2 Gel permeation chromatograms in DMF of acetal- $\mathrm{PEO}_{4000}-\mathrm{OH}$ (A, line), acetal- $\mathrm{PEO}_{4000}-b$ - $\mathrm{PCL}_{2600}(\mathrm{~B}$, double lines) and aldehyde$\mathrm{PEO}_{4000}-b-\mathrm{PCL}_{2600}(\mathrm{C}$, dashed line). copolymers, micelles have a diameter between 14 and $40 \mathrm{~nm}$ with a size distribution between 0.2 and 0.3 . As expected, for a same PEO block, increasing the size of the hydrophobic block increases the size of the micelles.

To these micellar solutions was added an equimolar (relative to the aldehyde functions) aqueous solution of the contrast agent $\left(\mathrm{NH}_{2}-\mathrm{Bn}-\mathrm{DTPA}\left(\mathrm{Gd}^{3+}\right)\right)$ prepared by chelation of gadolinium cations by the commercially available $\mathrm{NH}_{2}$-Bn-DTPA. After reaction of the amino group of $\mathrm{NH}_{2}-\mathrm{Bn}-\mathrm{DTPA}\left(\mathrm{Gd}^{3+}\right)$ with the aldehyde moieties at the micelle surface, an excess of sodium cyanoborohydride $\left(\mathrm{NaBH}_{3} \mathrm{CN}\right)$ was added to reduce the soformed imine into the corresponding stable amine moieties. For each copolymer, the reaction yield was equal to $60 \%$ as determined by ICP analysis of the gadolinium content after removing the ungrafted $\mathrm{NH}_{2}-\mathrm{Bn}-\mathrm{DTPA}\left(\mathrm{Gd}^{3+}\right)$ by micelles dialysis. The average diameter and size distribution of the DTPA $\left(\mathrm{Gd}^{3+}\right)$-PEO$b$-PCL were measured by DLS (Table 1) and compared with the average diameter of the aldehyde-copolymers. Micelles have a diameter between 20 and $50 \mathrm{~nm}$ with a size distribution between 0.18 and 0.3 . As expected, grafting of $\mathrm{NH}_{2}-\mathrm{Bn}-\mathrm{DTPA}\left(\mathrm{Gd}^{3+}\right)$ on aldehyde-PEO- $b$-PCL increases the size of the micelles.

\section{Relaxivities of the DTPA $\left(\mathrm{Gd}^{3+}\right)$-PEO-b-PCL micelles}

The contrasting efficiencies of the synthesized macrocontrast agents (DTPA $\left(\mathrm{Gd}^{3+}\right)$-PEO- $b$-PCL) in micellar form are compared in Table 2 . The relaxivity $\left(r_{1}\right)$ of the different contrast agents was calculated from formula 1 after determining the longitudinal relaxation time $\left(T_{1}\right)$ of water protons. ${ }^{34,35}$

$$
\frac{1}{T_{1, \mathrm{obs}}}=r_{1}\left[\mathrm{Gd}^{3+}\right]+\frac{1}{T_{1, \mathrm{H}_{2} \mathrm{O}}}
$$

where $T_{1, \mathrm{obs}}$ and $T_{1, \mathrm{H}_{2} \mathrm{O}}$ are the longitudinal relaxation times in the presence and in the absence of the MR contrast agent [2.86 s], respectively, and $\left[\mathrm{Gd}^{3+}\right]$ is the concentration of the contrast agent in $\mathrm{mM}$.

The relaxivities of the different macrocontrast agents at $20 \mathrm{MHz}$ were found to vary between 9 and $12 \mathrm{mmol}^{-1} \mathrm{~s}^{-1}$ and are significantly higher than that of the free and low molecular weight contrast agent DTPA $\left(\mathrm{Gd}^{3+}\right)\left(r_{1}=4.3 \mathrm{mmol}^{-1} \mathrm{~s}^{-1}\right)$ (Table $2)$. The relaxivity enhancements noted for the macrocontrast agents result from an increase of their rotational correlation lifetime due to their bulkiness. The observed enhancements are only slightly lower than other micellar systems based on gadolinium $\left(r_{1} \approx 18 \mathrm{mmol}^{-1} \mathrm{~s}^{-1}\right.$ at $20 \mathrm{MHz}$ ) because of the high flexibility of the PEO chains of our PEO- $b$-PCL micelles.

Table 2 Data of DTPA $\left(\mathrm{Gd}^{3+}\right)$-PEO- $b$-PCL block copolymer micelles and their relaxivities at $20 \mathrm{MHz}$

\begin{tabular}{lccc}
\hline Entry & $\begin{array}{l}\text { Copolymer } \\
\text { PEO- } b \text {-PCL }\end{array}$ & $\begin{array}{l}\text { Relaxation time } / \mathrm{ms} \\
\left(20 \mathrm{MHz}, 25^{\circ} \mathrm{C}\right)\end{array}$ & Relaxivity $/ \mathrm{mM}^{-1} \mathrm{~s}^{-1}$ \\
\hline 1 & $1300-b-1500$ & 84.3 & $11.9( \pm 0.2)$ \\
2 & $1300-b-3000$ & 107.2 & $9.3( \pm 0.2)$ \\
3 & $2500-b-1200$ & 85.1 & $11.8( \pm 0.1)$ \\
4 & $2500-b-2000$ & 84.5 & $11.8( \pm 0.2)$ \\
5 & $2500-b-5000$ & 106 & $9.4( \pm 0.1)$ \\
6 & $4000-b-1600$ & 97.2 & $10.3( \pm 0.2)$ \\
7 & $4000-b-2600$ & 99.2 & $10.1( \pm 0.1)$ \\
\hline
\end{tabular}


Comparing the characteristics of the micelles prepared using the different PEO- $b$-PCL block copolymers (Table 1) and the relaxivities of the corresponding DTPA $\left(\mathrm{Gd}^{3+}\right)$-PEO- $b$-PCL micelles at $20 \mathrm{MHz}$ (Table 2) clearly shows that there is no simple relationship between the size of the micelles and the relaxivities. Most of the relaxivities are in the same range $\left(10 \leq r_{1} \leq\right.$ $12 \mathrm{mmol}^{-1} \mathrm{~s}^{-1}$ ), except for the micelles formed from the block copolymers with the PCL sequence longer than the PEO one $\left(r_{1} \approx 9.5 \mathrm{mmol}^{-1} \mathrm{~s}^{-1}\right.$, Table 2 entries 2 and 5$)$.

Full relaxometric data were measured for two DTPA $\left(\mathrm{Gd}^{3+}\right)$ PEO- $b$-PCL based micelles over a large magnetic field range (from 0.01 to $100 \mathrm{MHz}$ ) and were compared to DTPA $\left(\mathrm{Gd}^{3+}\right)$ (Fig. 3). At low frequency ( 0.01 to $5 \mathrm{MHz}$ ), the relaxivity of the macrocontrast agent is about twice higher than that of free DTPA $\left(\mathrm{Gd}^{3+}\right)$. Importantly, the effect of the immobilization of gadolinium on micelles has an even more pronounced effect on relaxivity at high frequencies (10 to $80 \mathrm{MHz}$ ). Indeed, the micelle relaxivities remain strongly enhanced when compared to DTPA $\left(\mathrm{Gd}^{3+}\right)$ whose relaxivity drops drastically to $4 \mathrm{mM}^{-1} \mathrm{~s}^{-1}$. The maximum relaxivity for the best macrocontrast agent we have developed, i.e. $\mathrm{DTPA}\left(\mathrm{Gd}^{3+}\right)-\mathrm{PEO}_{1300}-b-\mathrm{PCL}_{1500}$, was obtained at $40 \mathrm{MHz}\left(r_{1}=12.6 \mathrm{mM}^{-1} \mathrm{~s}^{-1}\right)$ with a $300 \%$ relaxivity increase upon attachment of DTPA $\left(\mathrm{Gd}^{3+}\right)$ onto the micelles by comparison with free DTPA $\left(\mathrm{Gd}^{3+}\right)$. Once again, when the PCL sequence of the PEO- $b$-PCL block copolymer is longer than the PEO one, the relaxivities are lower. Symmetrical PEO-b-PCL or block copolymers with a shorter PCL sequence are thus preferred for optimized relaxivities.

\section{Complement activation test ${ }^{36}$}

The improvement of the relaxivity of a contrast agent by immobilizing it onto polymeric micelles is the first step towards the reduction of the dose needed for satisfactory image acquisition. The second step consists in preventing the recognition of the macrocontrast agent by the immune system that is responsible for its rapid elimination from the blood circulation, restricting timing for studies. For that purpose, poly(ethylene oxide) is the most popular polymer used for imparting stealthiness to molecules or particles injected in the body. ${ }^{37-41}$

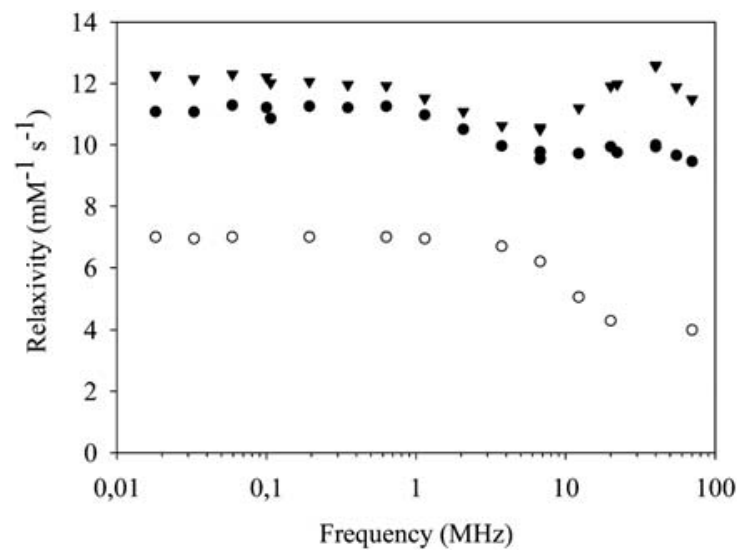

Fig. 3 Comparison of the ${ }^{1} \mathrm{H}$ NMRD profiles of DTPA $\left(\mathrm{Gd}^{3+}\right) \mathrm{PEO}_{1300^{-}}$ $b$ - $\mathrm{PCL}_{1500}$ (full triangles), DTPA $\left(\mathrm{Gd}^{3+}\right) \mathrm{PEO}_{2500}-b-\mathrm{PCL}_{5000}$ (full circles) and $\mathrm{NH}_{2}-\mathrm{Bn}-\mathrm{DTPA}\left(\mathrm{Gd}^{3+}\right)$ (empty circles) at $298 \mathrm{~K}$.

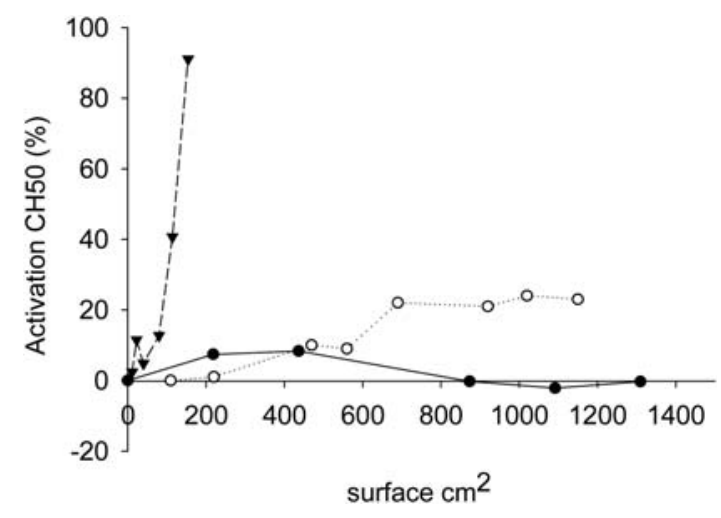

Fig. 4 Consumption of CH50 unit's vs. surface area of DTPA $\left(\mathrm{Gd}^{3+}\right)$ $\mathrm{PEO}_{2500}-b-\mathrm{PCL}_{5000}$ (full circles), $\mathrm{P}(\mathrm{MMA}-c o-\mathrm{MA})$ (full triangles) and $\mathrm{PEO}_{4900}-b-\mathrm{PCL}_{3900}$ (empty circles).

The PEO corona at the macrocontrast agent surface should therefore improve its blood circulation time. One of the macrocontrast agents (DTPA $\left.\left(\mathrm{Gd}^{3+}\right)-\mathrm{PEO}_{2500}-b-\mathrm{PCL}_{5000}\right)$ was therefore evaluated by the hemolytic $\mathrm{CH} 50$ test and compared to a $\mathrm{PEO}_{4900}-b-\mathrm{PCL}_{3900}$ block copolymer known for stealthiness. ${ }^{42}$ Both copolymers are very poor activators of the complement system in comparison with a P(MMA-co-MA) copolymer chosen as positive control ${ }^{43}$ (Fig. 4). Interestingly, Fig. 4 clearly shows that the grafting of the gadolinium complex onto PEO- $b$-PCL micelles does not activate the complement. This very low activation means that the macrocontrast agent is expected to have a long blood circulation time and could be ready to be evaluated by in vivo test like plasma clearance test.

\section{Conclusion}

Aldehyde functionalized micelles based on a hydrophilic corona of poly(ethylene oxide) and a hydrophobic core of poly( $\varepsilon$-caprolactone) were prepared in water and grafted with a gadolinium based contrast agent. Relaxometry measurements of these novel micellar macrocontrast agents have evidenced the strong increase (up to $300 \%$ ) of relaxivity at high frequencies compared to low molecular weight contrast agents due to the decrease of their tumbling rate in solution. Moreover, the hemolytic $\mathrm{CH} 50$ test has demonstrated that the PEO chains at the surface of the macrocontrast agents prevent their recognition by the immune system, imparting long-circulating properties to molecules. The improved relaxivity and the potential long circulation time of the macrocontrast agent make them good potential candidates for MRI blood pool contrast agent.

\section{Acknowledgements}

C.D., M.G. and C.J. are much indebted to the "Politique Scientifique Fédérale" for financial support in the frame of the " Interuniversity Attraction Pôles Programme (IAP VI/27): Supramolecular Chemistry and Supramolecular Catalysis » and to the National Funds for Scientific Research (F.R.S.-FNRS). The authors also thank Dr Jérôme Bejaud [Ingénierie de la Vectorisation Particulaire (Inserm) - Angers, France] for skilful assistance in $\mathrm{CH} 50$ tests. J.F.D. gratefully thanks the FNRS and the IISN of Belgium for financial support. 


\section{References}

1 M. Rudin and R. Weissleder, Nat. Rev. Drug Discovery, 2003, 2, 123-131.

2 P. Caravan, Chem. Soc. Rev., 2006, 35, 512-523.

3 R. B. Clarkson, Top. Curr. Chem., 2002, 221, 201-235.

4 P. Hermann, J. Kotek, V. Kubicek and I. Lukes, Dalton Trans., 2008, 3027-3047.

5 E. Toth, L. Helm and A. E. Merbach, Top. Curr. Chem., 2002, 221, 61-101.

6 R. B. Lauffer, T. J. Brady, R. D. Brown, III, C. Baglin and S. H. Koenig, Magn. Reson. Med., 1986, 3, 541-548.

7 P. Niemi, T. Reisto, I. Hemmila and M. Kormano, Invest. Radiol., 1991, 26, 820-824.

8 H. Paajanen, T. Reisto, I. Hemmila, M. Komu, P. Niemi and M. Kormano, Magn. Reson. Med., 1990, 13, 38-43.

9 U. Schmiedl, M. E. Moseley, M. D. Ogan, W. M. Chew and R. C. Brasch, J. Comput.-Assisted Tomogr., 1987, 11, 306-313.

10 M. Spanoghe, D. Lanens, R. Dommisse, A. Van der Linden and F. Alder Weireldt, Magn. Reson. Imaging, 1992, 10, 913-917.

11 G. Schuhmann-Giampieri, H. Schmitt-Willich, T. Frenzel, W. R. Press and H. J. Weinmann, Invest. Radiol., 1991, 26, 969-974.

12 L. H. Bryant, Jr, M. W. Brechbiel, C. Wu, J. W. Bulte, V. Herynek and J. A. Frank, J. Magn. Reson. Imaging, 1999, 9, 348-352.

13 Z. Jaszberenyi, L. Moriggi, P. Schmidt, C. Weidensteiner, R. Kneuer, A. E. Merbach, L. Helm and E. Toth, JBIC, J. Biol. Inorg. Chem., 2007, 12, 406-420.

14 J. Rudovsky, M. Botta, P. Hermann, K. I. Hardcastle, I. Lukes and S. Aime, Bioconjugate Chem., 2006, 17, 975-987.

15 R. Rebizak, M. Schaefer and E. Dellacherie, Bioconjugate Chem., 1997, 8, 605-610.

16 R. Rebizak, M. Schaefer and E. Dellacherie, Bioconjugate Chem., 1998, 9, 94-99.

17 J. P. Andre, E. Toth, H. Fischer, A. Seelig, H. R. Macke and A. E. Merbach, Chem.-Eur. J., 1999, 5, 2977-2983.

18 E. Nakamura, K. Makino, T. Okano, T. Yamamoto and M. Yokoyama, J. Controlled Release, 2006, 114, 325-333.

19 G. Zhang, R. Zhang, X. Wen, L. Li and C. Li, Biomacromolecules, 2008, 9, 36-42.

20 A. Accardo, D. Tesauro, G. Morelli, E. Gianolio, S. Aime, M. Vaccaro, G. Mangiapia, L. Paduano and K. Schillen, JBIC, $J$. Biol. Inorg. Chem., 2007, 12, 267-276.

21 A. J. L. Villaraza, A. Bumb and M. W. Brechbiel, Chem. Rev., 2010, 110, 2921-2959.
22 A. L. Ayyagari, X. Zhang, K. B. Ghaghada, A. Annapragada, X. Hu and R. V. Bellamkonda, Magn. Reson. Med., 2006, 55, 1023-1029.

23 W. J. M. Mulder, G. J. Strijkers, J. W. Habets, E. J. W. Bleeker, D. W. J. van der Schaft, G. Storm, G. A. Koning, A. W. Griffioen and K. Nicolay, FASEB J., 2005, 19, 2008-2010.

24 M. E. Fox, F. C. Szoka and J. M. J. Frechet, Acc. Chem. Res., 2009, 42, 1141-1151.

25 H. Maeda, G. Y. Bharate and J. Daruwalla, Eur. J. Pharm. Biopharm., 2009, 71, 409-419.

26 T. Seki and H. Maeda, Kekkan Igaku, 2008, 9, 397-409.

27 Y. Nagasaki, T. Okada, C. Scholz, M. Iijima, M. Kato and K. Kataoka, Macromolecules, 1998, 31, 1473-1479.

28 C. Scholz, M. Iijima, Y. Nagasaki and K. Kataoka, Macromolecules, 1995, 28, 7295-7297.

29 X. Shuai, H. Ai, N. Nasongkla, S. Kim and J. Gao, J. Controlled Release, 2004, 98, 415-426.

30 A. Aqil, S. Vasseur, E. Duguet, C. Passirani, J. P. Benoit, A. Roch, R. Muller, R. Jerome and C. Jerome, Eur. Polym. J., 2008, 44, 3191-3199.

31 A. Vonarbourg, C. Passirani, P. Saulnier, P. Simard, J. C. Leroux and J. P. Benoit, J. Biomed. Mater. Res., Part A, 2006, 78a, 620-628.

32 C. Passirani, G. Barratt, J.-P. Devissaguet and D. Labarre, Life Sci., 1998, 62, 775-785.

33 Y. Zou, D. E. Brooks and J. N. Kizhakkedathu, Macromolecules, 2008, 41, 5393-5405.

34 R. B. Lauffer, Chem. Rev., 1987, 87, 901-927.

35 C. Vanasschen, PhD Thesis, University of Liège, 2009.

36 C. Passirani and J.-P. Benoit, Biomaterials for Delivery and Targeting of Proteins and Nucleic Acids, ed. Ram I. Mahato, 2005, pp. 187-230.

37 A. Vonarbourg, C. Passirani, P. Saulnier and J.-P. Benoit, Biomaterials, 2006, 27, 4356-4373.

38 K. Shiraishi, K. Kawano, T. Minowa, Y. Maitani and M. Yokoyama, J. Controlled Release, 2009, 136, 14-20.

39 V. P. Torchilin, Adv. Drug Delivery Rev., 2002, 54, 235-252.

40 R. Gref, M. Luck, P. Quellec, M. Marchand, E. Dellacherie, S. Harnisch, T. Blunk and R. H. Muller, Colloids Surf., B, 2000, 18, 301-313.

41 E. Owens Donald, 3rd and A. Peppas Nicholas, Int. J. Pharm., 2006, 307, 93-102.

42 K. Van Butsele, P. Sibret, C. A. Fustin, J. F. Gohy, C. Passirani, J. P. Benoit, R. Jerome and C. Jerome, J. Colloid Interface Sci., 2009, 329, 235-243.

43 J. Rieger, C. Passirani, J.-P. Benoit, K. Van Butsele, R. Jerome and C. Jerome, Adv. Funct. Mater., 2006, 16, 1506-1514. 